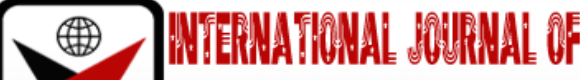

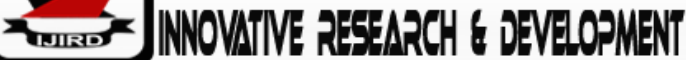

ISSN 2278-0211 (Online)

\section{Effect of Job Embeddedness and Job Satisfaction on Millennial Employee Performance with Turnover Intention as Mediation}

\author{
Qoni'atur Rohmatillah \\ Student, Department of Magister Management, Indonesian Islamic University, Indonesia
}

\begin{abstract}
:
This research discusses the influence of job embeddedness and job satisfaction on employee performance through turnover intention as mediation. The variables in this study are job embeddedness, job satisfaction, turnover intention, and employee performance. This study used random sampling techniques with the criteria: millennial age and permanent employees who work at least 1 year. Respondents in this study numbered 91 employees. The test equipment used is SPSS version 21 with Multiple Linear Regression analysis method, Path Analysis, and Sobel Test. The results of this study showed that Job Embeddedness and job satisfaction have a significant negative effect on turnover intention, turnover intention has a significant negative effect on employee performance, in addition job embeddedness and job satisfaction have a positive effect on employee performance, and turnover intention is able to mediate between job embeddedness and job satisfaction on employee performance.
\end{abstract}

Keywords: Job embeddedness, job satisfaction, turnover intention, and employee performance

\section{Introduction}

The term millennials was first issued by William Strauss and Neil in his book Millennials Rising: The Next Great Generation (2000). William and Neil created the term millennial in 1982. Another opinion was expressed by Elwood Carlson in his book Entitled The Lucky Few: Between the Greatest Generation and the Baby Boom (2008), millennials are those born between 1983 and 2001.

According to Budiati et.al (2018), millennials have a unique character based on region and socio-economic conditions. One of the main characteristics of millennials is characterized by increased use and familiarity with communication, media, and digital technology. By using these devices millennials can become more productive and efficient individuals. From these devices they are able to do anything from just texting, accessing educational sites, transacting business online, to order online transportation services. Millennials have vast opportunities and opportunities to innovate. The creation of a digital ecosystem succeeded in creating a variety of business fields to grow mushrooming in Indonesia; for example, the trade and transportation sector. In addition, in terms of education, millennials also have superior quality. Where he has an interest in continuing higher tiered education. They realize that education is a top priority. The performance performed by millennial employees is an important focus, as millennials prefer flexible work, demand creativity and provide opportunities for them to have an impact on the company itself.

Netindo Solution Group or commonly referred to as Netsolmind is a company in the field of information technology development for business interests. The company has many years of experience in carrying out specific relationships with complex market plans and greatly tailoring the needs of consumers. Netsolmind company presents conveniences for users who do not understand information technology though. In addition, convenience and security are professionally controlled. The company has a long and varied experience, namely: business consultants, technology scope, marketing, operations, human resources, and finance.

Netsolmind has concerns about employees at the age of millennials who have the intention to turnover in their jobs on the grounds of moving jobs. These employees are dominated by employees of the progammer section under the age of 20 who fall into the millennial age category.

\section{Literature Review and Hipotesis}

According to Mitchell et.al (2001) job embeddedness is a combined force that keeps employees attached to their work. Meanwhile, according to Sekiguchi (2008) job embeddedness is a concept of job stability that explains why people stay in their company. Job Embeddedness can be categorized as conformity, relationships, community, sacrifice between employees and organizations or companies. Job embeddedness can be measured by these things. The more attached an employee is to his company, the more likely it is that the employee remains in his current job (Holtom and Neil in Reitz 2011). 
According to Davis (2011) that "Job satisfaction is the favorableness or unfavorableness with employees view their work". Employees will be satisfied in working if the aspects of work with aspects that exist in line (Erni, et al, 2018). Human Resource Management (MSDM) experts and organization actors provide definitions or concepts of job satisfaction with different languages and fists from different points of view but still have the same meaning, where job satisfaction is a general attitude or feeling felt by an employee towards the work they do.

According to Issa, et.,al (2013) turnover intention means the intention to move voluntarily which will later affect the status of the company also affects the productivity of other employees. Saeka and Suana (2016) defined turnover intention as a result of individual evaluation of what he felt in the company, then expressed a desire to leave the organization.

Mangkunegara (2011) defines employee performance is the result of work in quality and quantity achieved by an employee in carrying out his duties in accordance with the responsibilities given to him. Performance reflects how well employees meet the requirements of a job. The performance of an employee is individual, because each employee has a different level of ability in doing their job. Management can measure employees for their performance based on the performance of each employee (Riski, 2018).

\subsection{Effect of Job Embeddedness on Turnover Intention}

Research conducted by Hussain and Deery (2018) using a sample of 204 revealed that job embeddedness negatively affects turnover intention. Coetzer et.al (2018) used a sample of 147 SME employees located in Perth, Western Australia and 350 employees from SMEs operating in four South African business centers revealed that job embeddedness and its various dimensions had a negative relationship to turnover intention.

Research conducted by Dechawatanapaisal (2017) using questionnaires with respondents as many as 1,028 accountants working at large companies in Thailand interaction effects showed a negative relationship between job embeddedness on turnover intention when job satisfaction is high. Research conducted by Rarasanti and Suana (2016) on pt employees. Luhur Permai's work with questionnaires as many as 147 results from this study is job embeddedness negatively and significantly affect turnover intention. Research conducted by Jiang, et.al (2012) using a sample of 65 found that on the job and off the job embeddedness is negatively related to the intention of turnover and actual turnover.

Thus, the higher the job embeddedness felt, the higher the intention to stay. On the contrary, if the lower the job embeddedness, the higher the intention for turnover.

- H1: Job embeddedness negatively affects turnover intention.

\subsection{The Effect of Job Satisfaction on Turnover Intention}

Research conducted by Mahdi et.al (2012) using questionnaires as many as 32 distributed to executives and nonexecutives from local printing companies found results that job satisfaction both intrinsic and extrinsic affect turnover. Lambert et.al (2001) shows that the work environment has an important role to play in the formation of job satisfaction, and that job satisfaction is a very influential role in turnover. So that the employee who feels the environment is good for him then he is satisfied with his work so as not to make turnover.

Research conducted by Li et.al (2019) conducted research in 13 Beijing public hospitals showed that workplace violence has a significant influence on turnover intentions, and job satisfaction has a significant negative influence on turnover. However, job satisfaction mediates workplace violence relationships against turnover. So that it can be concluded that, if there is violence in the workplace, it will reduce the satisfaction of an employee or nurse of the hospital resulting in the intention to commit turnover. Chen and Wang (2018) with questionnaires distributed to hotel chefs of tourists produced the finding that inactivity in the workplace has a very negative effect on job satisfaction, resulting in a positive effect on the intention to turnover. If the tourist feels satisfaction then he does not make turnovers.

Dole and Richard (2015) produced the finding that job satisfaction and turnover intentions had a negative relationship. Simone et. al (2018) in 194 nurses and 181 patients from 22 inpatient wards at two hospitals in the Southern Italy region, resulted in findings that job satisfaction, work engagement, self-efficacy and agency capacity were interconnected and correlated negatively with turnover intention.

The higher the satisfaction of an employee in his/her job, the lower the turnover intention. On the contrary, if an employee's job satisfaction is low, the higher the intention to turnover.

- H2: Job Satisfaction negatively affects turnover intentions.

\subsection{Effect of Turnover Intention on Employee Performance}

Research conducted by Watrous et.al (2006) found that turnover has a certain relationship to performance, both directly and moderation. Turnover that occurs can also vary in effect in each organization. Zimmerman and Darnold (2007) used 65 questionnaires distributed to employees, resulting in the finding that under-performing employees were more likely to commit turnover and even engage in unplanned terminations. Ton and Huckman (2008) revealed that over the past 48 months the average employee turnover was related to decreased performance. This decrease in performance can be noticed through the overall customer service score of the store.

Research conducted by Biron and Corine (2013) in the branch of an elderly care organization with questionnaire responses of 225 employees resulted in findings that performance assessed by individuals and assessed by managers both had a negative relationship to turnover intentions. Javed, et.al (2014) findings also show that there is no significant relationship between turnover intentions and employee empowerment and employee performance. Asmara (2017) produced the finding that turnover intention affects employee performance. 
The higher the turnover intention in employees, the lower the employee's performance, and vice versa if the lower the turnover intention, the higher the performance performed by employees.

- H3: Turnover intention negatively affects employee performance.

\subsection{The Effect of Job Embeddedness on Employee Performance}

Emmerik and Sanders (2004) found that there is a positive relationship between temporal embeddedness in compliance and performance. Work attachment in this study has a positive relationship with both types of job performance both who have tenure and do not have tenure. Karatepe and Vatankhah (2014) produced the finding that flight attendants who have longer working hours have an excellent working attachment to the team, while married flight attendants are more attached to their work. Therefore, flight attendants who have long worked for the company know better how to work and contribute to the team and the married do not sacrifice many benefits but have no intention of leaving the company.

Sekiguchi et.al (2008) with the aim of investigating the role of work attachment to OCB and performance, resulting in the finding that employment attachment has a direct but low impact on employee performance. Coetzer et.al (2018) found that embedded on the job has a positive and significant influence related to the innovative behavior of employees operating in various industries. NG and Feldman (2009) found that job attachment was positively related to task performance and creativity and negatively related to counterproductive work behavior, even after controlling for the effects of organizational attachment.

The higher the job embeddedness is felt, the more it improves employee performance, and vice versa if the job embeddedness is low then the performance is also lower.

- H4: Job Embeddednes positively affect employee performance.

- H6: Job Embeddedness affects employee performance by being mediated by turnover intention.

\subsection{The Effect of Job Satisfaction on Employee Performance}

Research conducted by Valaei and Jiroudi (2016) shows that all aspects of job satisfaction are positively related to performance except additional allowances, contingency rewards and communication. Siengthai and Ngarm (2015) showed that there is a positive and significant relationship between job satisfaction and employee performance. Gu and Siu (2008) The results of this study are that job satisfaction is significantly correlated with performance. There is a significant driver of job satisfaction, namely training, salaries, benefits and there is support between colleagues and leaders.

Shu et.al (2018) found that the effect of job satisfaction on performance is not very prominent for family members, but more significant for non-family members. Eliyana et.al (2019) found that job satisfaction and performance showed significant and positive results at mid-level leaders at Pelabuhan Indonesia III Inc. Crossman (2003) indicates the job satisfaction variable does not have a significant relationship to the Performance variable.

The higher the satisfaction felt by employees, the more improved the performance of employees, and vice versa if the employee's job satisfaction is low then the performance is also low.

- H5: Job Satisfaction has a positive effect on employee performance.

- H7: Job Satisfaction has a positive impact on employee performance mediated by turnover intention.

\section{Research Methods}

This research uses a descriptive quantitative approach. With a sample of 218 employees of PT. Netindo Solution Group, then uses random sampling techniques with the criteria: mielnial employees and permanent employees who have worked at least 1 year. So that the total respondents as many as 91 employees.

\subsection{Job Embeddedness}

According to Mitchell et.al (2001) in Sekiguchi et.al (2008), job embeddedness is part of the totality of strength that keeps employees in their jobs. The indicators in job embeddedness measurement are as follows, Setialestari (2015):

- Employee compatibility with organization

- Employee's suitability for employment

- Good relationships with colleagues

- Good relations with working group members

- Material benefits

- Psychological benefit.

\subsection{Job Satisfaction}

According to Davis (2011) that "Job satisfaction is the favorableness or unfavorableness with employees view their work". The indicators in measuring job satisfaction are as follows, Luthans (2015):

- Interesting work

- Proximity to Colleagues

- leaders

- Salary

- Promotional opportunities 


\subsection{Turnover Intention}

Saeka and Suana (2016) define turnover intention as a result of an individual's evaluation of what he feels in the organization or company, then expressed a desire to leave the organization.

The indicators in this study measurement are (Mobley, 2011):

- Thoughts of quitting work.

- Desire to leave.

- Desire to find a new job.

- Opportunity for a career.

- Other companies are more attractive.

\subsection{Employee Performance}

Mangkunegara (2011) defines employee performance is the result of work in quality and quantity achieved by an employee in carrying out his duties in accordance with the responsibilities given to him. The indicators in this measurement are as follows (Robbbins, 2006):

- Quality

- Quantity

- $\quad$ Effectiveness

- Punctuality

- $\quad$ Self-reliance

\section{Result}

\subsection{Test Validity}

Validity test is used to measure the validity of a questionnaire by using sigifikansi level of 0.05 (5\%).

\subsection{Reliability Test}

Reliability Test is used to obtain reliable results by using spss cornbach alpha $>0.6$.

\subsection{Inferential Analysis}

\subsubsection{Regression Analysis Model 1}

From the results of multiple linear regression analysis obtained the result of regression coefficient that connects Job Embeddedness variable and Job Satisfaction variable to Turnover Intention with the following equation: $\mathrm{Y}=-0,379 \mathrm{X}_{1}+-0,347 \mathrm{X}_{2} \rightarrow$ Standardized

\subsubsection{Affect coefficient testing (T Test)}

\subsection{Test the effect of Job Embeddedness on Turnover Intention}

As a result of data processing calculation, there is a coefficient of influence of -2,798 and significance of 0.006 which means that there is an influence between job embeddedness variables on turnover intention variables.

\subsection{Test the effect of Job Satisfaction on Turnover Intention}

As a result of data calculation, there is a coefficient of influence of $-2,560$ and significance of 0.012 which means that there is an influence between job satisfaction variables on turnover intention.

\subsubsection{Coefficient of Determination (R2)}

As a result of data calculation, there is a coefficient of influence of $-2,560$ and significance of 0.012 which means that there is an influence between job satisfaction variables on turnover intention.

\subsubsection{3.. Simultaneous Significance Test (Test F)}

Based on the results of the calculation processed data, obtained a significance value of 0.000 . Because the significance value is $0.000<0.05(\alpha=5 \%)$ this means that the variables Job Embeddedness and Job Satisfaction simultaneously (together) affect turnover intention. The lower the Job Embeddedness and Job Satisfaction of employees, the higher the Employee Turnover Intention.

\subsubsection{Regression Analysis Model 2}

From the results of multiple linear regression analysis obtained the results of the regression coefficient. The results of linear regression analysis can produce the following equations:

$\mathrm{Z}=0,254 \mathrm{X} 1+0,684 \mathrm{X} 2+-0,107 \mathrm{Y} \rightarrow$ standardized 


\subsubsection{Testing the Effect Coefficient ( $t$ test)}

\subsection{Test the Effect of Turnover Intention on Employee Performance}

The result of the data was found coefficient of $-3,782$ and significance of 0.000 . So we can conclude that there is an influence between the variable Turnover Intention on Employee Performance.

\subsubsection{Test the Effect of Job Embeddedness on Employee Performance}

The result of data calculation is a coefficient of 6,774 with a significance of 0.000 . So, Job Embeddedness affects Netindo Solution Group Employee Performance.

\subsubsection{Test the Effect of Job Satisfaction on Employee Performance}

The result of data calculation obtained coefficient of 18,352 and significance of 0.000 . Thus, Job Satisfaction has a significant effect on the Performance of Netindo Solution Group Employees.

\subsubsection{Coefficient of Determination (R2)}

Based on the results of the SPSS data, a double determination coefficient of 0.964 was obtained. This means that 96.4\% of Netindo Solution Group's Employee Performance is influenced by the three free variables consisting of Job Embeddedness, Job Satisfaction, and Turnover Intention. While the remaining 3.6\% were affected by other variables not included in the study.

\subsubsection{Simultaneous Significance Test (Test F)}

Based on the results of the calculation of processed data, obtained the probability value of significance of 0.000 . So we can know that $0.000<0.05(\alpha=5 \%)$, this means simultaneously (together) job embeddedness variables, Job Satisfaction variables, and Turnover Intention variables affect employee performance.

\section{Path Analysis}

Line Analysis is an extension of multiple regression analysis aimed at estimating the significance of relationships between multiple variables and involving intervening variables (Ghozali, 2006). The influence of analysis can be described as follows:

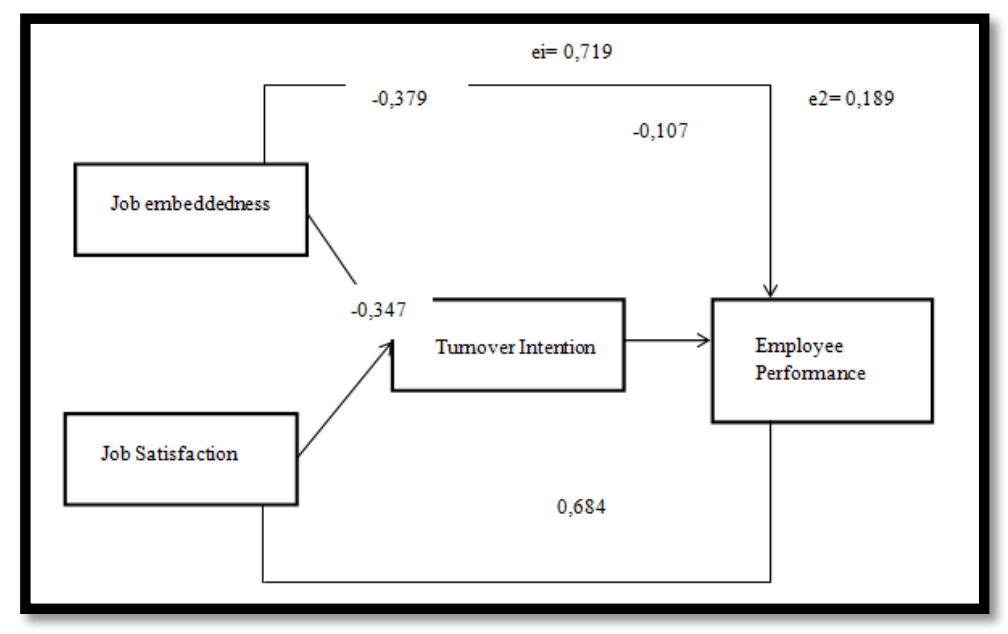

Figure 1

Based on the diagram above, it can be made a summary of the results with the following details: Mediation hypothesis testing is calculated using a procedure developed by Sobel (Ghozali, 2016).

\begin{tabular}{|l|c|c|c|}
\hline Direction of Influence & $\begin{array}{c}\text { Koefisien } \\
\text { Regresi }\end{array}$ & $\begin{array}{c}\text { Indirect } \\
\text { Effect }\end{array}$ & $\begin{array}{c}\text { Total } \\
\text { Effect }\end{array}$ \\
\hline$X_{1} \rightarrow \mathrm{Y}$ & $-0,379$ & - & - \\
\hline$X_{2} \rightarrow \mathrm{Y}$ & $-0,347$ & - & - \\
\hline$X_{1} \rightarrow \mathrm{Z}$ & 0,254 & - & - \\
\hline$X_{2} \rightarrow \mathrm{Z}$ & 0,684 & - & - \\
\hline $\mathrm{Y} \rightarrow \mathrm{Z}$ & $-0,107$ & - & - \\
\hline $\mathrm{X} 1 \rightarrow \mathrm{Y} \rightarrow \mathrm{Z}$ & - & 0,040553 & 0,294553 \\
\hline $\mathrm{X} 2 \rightarrow \mathrm{Y} \rightarrow \mathrm{Z}$ & - & 0,037129 & 0,721129 \\
\hline
\end{tabular}

Table 1: Result Test 


\subsection{Testing Mediation Effects 1}

$$
t=\frac{-0,379 \times-0,107}{\sqrt{-0,101^{2} 0,105^{2}+-0,379^{2} 0,079^{2}+0,105^{2} 0,079^{2}}}
$$

$=\frac{0,0405}{0,0109}=3,716$

From the results of the calculation of sobel test above, we can know that the value of $\mathrm{Z}$ is 3.716 . Because the value of 3.716

$>1.66256$ with a significance of 0.05 , it proves that Turnover Intention is able to mediate the influence of Job Embeddedness on Employee Performance.

\subsection{Testing Mediation Effects 2}

$$
t=\frac{-0,347 \times-0,107}{\sqrt{-0,107^{2} 0,121^{2}+-0,347^{2} 0,030^{2}+0,121^{2} 0,030^{2}}}
$$

$=\frac{0,037}{0,017}=2,183$

From the calculation of sobel test above, obtained $\mathrm{Z}$ value of 2,183, because $2.183>1.66256$ with a significance of 0.05 , turnover intention mediates the influence of Job Satisfaction on Employee Performance.

\section{Discussion}

\subsection{Job Embeddedness against Turnover Intention}

Job Embeddedness negatively affects Turnover Intention. Data processing and analysis of Job Embeddedness to Turnover Intention in accordance with the hypothesis that Job Embeddedness negatively affects Turnover Intention. Therefore, if the Job Embeddedness of employees is low, it will have a negative impact, namely increasing employee Turnover Intention.

\subsection{Job Satisfaction against Turnover Intention}

Job Satisfaction negatively affects Turnover Intention. Data processing and analysis of Job Satisfaction on Turnover Intention in accordance with the hypothesis that Job Satisfaction negatively affects Turnover Intention. That is, if employee Job Satisfaction is low, it will affect the increase in employee Turnover Intention.

\subsection{Turnover Intention to Employee Performance}

Turnover Intention negatively affects Employee Performance. Data processing and analysis of Turnover Intention on Employee Performance in accordance with the hypothesis that Turnover Intention negatively affects Employee Performance. That is, if turnover intention is high, it will affect employee performance, i.e. resulting in the decrease in quality and quantity of work.

\subsection{Job Embeddedness to Employee Performance}

Job Embeddedness positively affects Employee Performance. Data processing and analysis of Job Embeddedness to Employee Performance in accordance with the hypothesis that Job Embeddedness has a positive effect on Employee Performance. That is, if the Job Embeddedness of employees is high, it will improve employee performance.

\subsection{Job Satisfaction to Employee Performance}

Job Satisfaction has a positive effect on Employee Performance. Data processing and analysis of Job Satisfaction on Employee Performance in accordance with the hypothesis that Job Satisfaction has a positive effect on Employee Performance. That is, if the Employee Job Satisfaction is high then the Employee Performance is also high.

\subsection{Job Embeddedness to Employee Performance through Turnover Intention}

The results of the data process state that Turnover Intention is able to mediate the relationship of Job Embeddedness to Employee Performance.

\subsection{Job Satisfaction to Employee Performance through Turnover Intention.}

The result of the data process states that Turnover Intention is able to mediate the relationship of Job Satisfaction to Employee Performance.

\section{References}

i. Afsar, Bilal, Asad Shahjehan dan Syed Imad Shah. 2018. Frontline Employee's High Performance Work Practices, Trut in Supervisor, Job Embeddedness and Turnover Intention in Hospitality Industry. International Journal of Contemporary Hospitality Management. 30(3), 1436-1452.

ii. Ajiputra, Mirza Setiawan, Ahyar Yuniawan. 2016. Analisis Pengaruh Job Insecurity Dan Kepuasan Kompensasi Terhadap Turnover Intention Serta Dampaknya Pada Kinerja Karyawan (Studi Pada PDAM Kabupaten Semarang). Diponegoro Journal of Management. 5(1), 1-15.

iii. Asmara, Alfatania Pandu. 2017. Pengaruh turnover intention terhadap Kinerja Karyawan di Rumah Sakit Bedah Surabaya. Jurnal Administrasi Kesehatan Indonesia. 5(2), 123-129.

iv. Bagia, Wayan, 2015. Perilaku Organisasi. Grha Ilmu: Yogyakarta. 
v. Biron, Michal dan Corine Boon. 2013. Performance and Turnover Intentions: A Social Exchange Perspective. Journal of managerial Psychology. 28(5), 511-531.

vi. Budiati, Indah, Yuni Susianto, Windhiarso Ponco, Sofaria Ayuni, Henri Asri Reagan, Putri Larasaty. Nia Setyawati, Aprilia Ira Pratiwi, dan Valent Gigih Saputri. 2018. Profil Generasi Milenial Indonesia. Statistik Gender Tematik. Kerjasama Kementerian Pemberdayaan Perempuan Dan Perlindungan Anak dengan Badan Pusat Statistik : Jakarta.

vii. Chen, Hsi Tien dan Chih Hung Wang. 2018. Incivility, satisfaction and turnover intention of tourist hotel chefs: moderating effects of emotional intelligence. International Journal of Contemporary Hospitality Management. 31(5), 2034-2053.

viii. Coetzer, Alan, Chutarat Inma, Paul Poisat, Janice Redmond, dan Craig Standing. 2018. Does Job Embeddedness predict Turnover Intentions in SMEs?. International Journal of Productivity and Performance Management. 68(2), 340-361.

ix. Coetzer, Alan, Chutarat Inma, Paul Poisat, Janice Redmond, Craig Standing. Job Embeddedness and employee enactment of innovation related work behaviours. International Journal Of Manpower. 39(2), 222-239.

x. Crossman, Alf. 2003. Job satisfaction and employee performance of Lebanese banking staff. Journal of managerial psychology. 18(4), 368-376.

xi. Damodar N., Gujarati dan Dawn C. Porter. 2009. Basic Econometric 5th Edition. McGraw - Hill: New York.

xii. Davis Keith, William Frederick, (2011), Perilaku Dalam Organisasi, Edisi ke tujuh, Jilid kedua. Erlangga: Jakarta.

xiii. Dechawatanapaisal, Decha. 2017. Examining the Relationships between HR practices, Organizational Job Embeddedness, Job Satisfaction, and Quit Intention. Asia-Pasific Journal of Bussiness Administration. 10(2/3), 130-148.

xiv. Dharma, Surya. 2012. Manajemen Kinerja Falsafah Teori dan Penerapannya. Yogyakarta: Pustaka Pelajar.

xv. Dole, Carol dan Richard G. Schroeder. 2015. The impact of various factors on the personality, job satisfaction and turnover intentions of professional accountans. Manajerial auditing journal. 16(4), 234-245.

xvi. Donnelly, James H., James L. Gibson dan John M. Ivancevich. 2003. Fundamentals of Management. Business Publication: Texas.

xvii. Echols, J.M dan Hassan S. 2000. Kamus Inggris-Indonesia. Jakarta: Gramedia.

xviii. Eliyana, Anis, Syamsul Ma'rif, dan Muzakki. Job satisfaction and organizational commitment effect in the transformational leadership towards employee performance. European Research on Management and Business Economics. 25(3), 144-150.

xix. Emmerik, Hetty Van dan Karin Sanders. 2004. Social Embeddedness and Job Performance of tenured and nontenured professionals. Human Resource Management Journal. 14(1), 40-54.

xx. Ghozali, Imam. 2016. Aplikasi Analisis Multivariete dengan Program IBM SPSS 23 (Edisi 8). Cetakan ke VIII. Badan Penerbit Universitas Diponegoro: Semarang.

xxi. Ghozali, Imam. 2018. Aplikasi Analisis Multivariate dengan Program IBM SPSS 25. Badan Penerbit Universitas Diponegoro: Semarang

xxii. Gu, Zheng, dan Ricardo Chi Sen Siu. 2008. Drivers of Job Satisfaction As Related To Work Performance In Macao Casino Hotels. An Investigation Based On Employee Survey. International Journal Of Contemporary Hosppitality Management. 21(5), 561-578.

xxiii. Harnoto, 2002. Manajemen Sumber Daya Manusia. Edisi Kedua. PT. Prehallindo: Jakarta

xxiv. Hussain, Taiba, dan Stephen Deery. 2018. Why do Self-initiated expatries quit their jobs: The Role of Job Embeddedness and Shocks in Explaining Turnover Intentions? International Business Review. 27(1), $281-288$.

xxv. Hom, P. W., Mitchell, T. R., Lee, T. W., \& Griffeth, R. W. 2012. Reviewing employee turnover: Focusing on proximal withdrawal states and an expanded criterion. Psychological Bulletin. 138(5), 831-858

xxvi. Issa, D.A.R, Ahmad, F dan Gelaidan, H.M. 2013. Job satisfaction and turnover Intention Based on Sales Person Standpoint. Middle East Journal of Scientific Research. 14(4), 523-531.

xxvii. Javed, Masooma, Rifat Balouch, dan Fatima Hassan. Determinan of Job Satisfaction and its Impact on Employee Performance and Turnover Intentions. International Journal of Learning \& Development. 4(2), 120-140.

xxviii. Jiang, Kaifeng, Patrick F. McKay, Dong Liu, Thomas W. Lee dan Terence R. Mitchell. 2012. When and How Is Job Embeddedness Predictive of Turnover? A Meta-Analytic Investigation. Journal of Applied Psychology. 97(5), 1077-1096.

xxix. Karatepe, Osman M. 2012. The Effects of Work Overload And Work Family Conflict On Job Embeddedness And Job Performance, The Mediation Of Emotional Exhaustion. International Journal of Contemporary Hospitality Management. 25(4), 614-634.

xxx. Karatepe, Osman M dan Sanaz Vatankhah. 2014. The Effect of high-performance work practices and Job Embeddedness on flight attendants' performance outcomes. Journal of Air Transport Management. 37, 27-35

xxxi. Kasiram, Moh. 2008. Metodologi Penelitian. UIN-Malang Pers: Malang.

xxxii. Kuncoro, Mudrajad. 2018. Metode Kuantitatif. Unit penerbit dan Percetakan Sekolah Tinggi Ilmu Manajemen YKPN: Yogyakarta.

xxxiii. Lambert, Eric G, Nancy Lynne Hogan, Shannon M. Barton. 2001. The Impact of Job Satisfaction On Turnover Intent: A Test Of A Structural Measurement Model Using A National Sample Of Workers. The Social Science Journal. 38(2), 233-250. 
xxxiv. Lee, Ye Hoon dan Packianathan Chelladurai. 2017. Emotional Intelligence, Emotional Labor, Coach Burnout, Job Satisfaction, and Turnover Intention In Sport Leadership. European sport management quarterly. 18(4), 393412.

xxxv. Lee, Thomas W, Terence R. Mitchell, Chris J. Sablynski, James P. Burton, Brooks C. Holtom. 2004. The Effects Of Job Embeddedness On Organizational Citizenship, Job Performance, Volitional Absences, And Voluntary Turnover. Academy of Management Journal. 47(5), 711-722.

xxxvi. Li, Na, Lichuan Zhang, Guangqing Xiao, Jie Chen, dan Qian Lu. 2019. The Relationship between workplace violence, job satisfaction and turnover intention in emergency nurses. International Emergency Nursing. 45, 5055.

xxxvii. Luthans, Fred. 2005. Organizational Behavior 10th Edition. Alih Bahasa: Vivin Andhika, dkk. ANDI: Yogyakarta.

xxxviii. Mahdi, Ahmad Faisal, Mohammad Zaid Mohd Zin, Mohd Roslan Mohd Nor, Ahamad Asmadi Sakat dan Abang Sulaiman Abang Naim. 2012. The Relationship Between Job satisfaction and Turnover Intention. American Journal of Applied Sciences. 9(9), 1518-1526.

xxxix. Mangkunegara, Anwar Prabu. 2002. Manajemen Sumber Daya Manusia Perusahaan. PT. Remaja Rosda Karya: Bandung.

xl. Mangkunegara, Anwar, 2011. Manajemen Sumber Daya Manusia Perusahaan. PT. Remaja Rosda Karya: Bandung.

xli. Mathis. L. Robert dan Jackson. H. John. 2001. Manajemen Sumber Daya Manusia. Salemba Empat: Jakarta.

xlii. Mobley, W. H. 1986. Pergantian Karyawan: Sebab, Akibat dan pengendaliannya. Alih bahasa: Nurul Imam. Jakarta: PT. Pustaka Binaman Pressindo.

xliii. Mobley, Horner dan Hollingsworth. 2011. Pergantian Karyawan: Sebab, Akibat dan Pengendaliannya. Alih Bahasa: Nurul Imam. PT Pustaka Binaman Pressindo: Jakarta.

xliv. Newman, Alexander, Ingrid Nielsen, Russell Smyth, dan Angus Hooke. 2014. Examining the Relationship Between Workplace Support and Life Satisfaction: The Mediating Role of Job Satisfaction. Social Indicators Research. 120(3) 769-781.

xlv. Notoatmodjo, S. 2010. Metodologi Penelitian Kesehatan. Rineka Cipta: Jakarta.

xlvi. Paripurna, I Gede Diatmika, I wayan Gede Supartha dan Made Subudi. Pengaruh Kepemimpinan Dan Kepuasan Kerja Terhadap Turnover Intention Serta Dampaknya Terhadap Kinerja Karyawan Pada PT. Agung Automall Kuta. E-Journal Ekonomi dan Bisnis Universitas Udayana. 6(6), 2441-2474.

xlvii. Pekasa, Elvina dan Rostiana. 2018. Peran Job Embeddedness Terhadap Kinerja Dengan Keterikatan Kerja Dan Keinginan Untuk Menetap Sebagai Mediator. Jurnal Muara Ilmu Sosial, Humaniora, dan Seni. 2(1), 335-341.

xlviii. Shu, Xiaobin, Yeming Gong, Jie Xiong, dan Xin Hu. 2018. Job Satisfaction, Turnover Intention And Work Performance In Chinese Family Enterprises. Management International. 22(2), 84-95.

xlix. Sugiyono. 2017. Metode Penelitian Kuantitatif, Kualitatif, dan R\&D. Alfabeta, CV: Bandung.

l. Ton, Zeynep, dan Robert S. Huckman. 2008. Managing the Impact of Employee Turnover on Performance: The Role of Process Conformance. Organization Science. 19(1), 56-68.

li. Yudha, Putu, Asteria Putri dan Made Yenni Latrini. 2013. Pengaruh Kepuasan Kerja Terhadap Kinerja Karyawan Sektor Publik, Dengan In-Role Performance Dan Innovative Performance Sebagai Variabel Mediasi. E-Jurnal Akuntansi Universitas Udayana. 5(3), 627-638.

lii. Rarasanti, Ida Ayu, dan I Wayan Suana. 2016. Pengaruh Job Embeddedness, Kepuasan Kerja, Dan Komitmen Organisasional Terhadap Turnover Intention Karyawan. E-Jurnal Manajemen Unud. 5(7), 4690-4718.

liii. Reitz, O. ED, PhD MBA, RN, dan Mary Ann Anderson, PhD, RN. 2011. An Overview of Job Embeddedness. Journal of Professional Nursing. 27(5), 320-327.

liv. Riadi, Sukisno S. 2016. Dampak Kepuasan Kerja Terhadap Turnover Intention Dengan Job Performance Sebagai Mediasi Pada Pegawai Pada Perusahaan Jasa Di Samarinda. Conference on Management and Behavioral Studies. 5, 127-136.

lv. Rismayanti, Revilia Dian, Mochammad Al Musadieq, dan Edlyn Khoirotul Aini. 2018. Pengaruh Kepuasan Kerja Terhadap Turnover Intention Serta Dampaknya Pada Kinerja Karyawan (Studi Pada Karyawan Tetap Pg Kebon Agung Malang). Jurnal Administrasi Bisnis (JAB). 61(2), 118-126.

lvi. Robbins, Stephen P. 2006. Perilaku Organisasi. PT Indeks, Kelompok Gramedia: Jakarta.

lvii. Robbins, Stephen dan Judge Timothy A. 2013. Organizational Behaviour Edition 15. New Jersey. Pearson Education.

lviii. Robbins, Stephen dan Judge Timothy A. 2015. Perilaku organisasi Edisi 16. Jakarta: Salemba Empat.

lix. Saeka, A.P., dan Suana. 2016. Pengaruh Kepuasan Kerja, Komitmen Organisasional dan Stres Kerja Terhadap Turnover Intention Karyawan PT. Indonusa Algaemas Prima Bali. E-Jurnal Manajemen Unud. 5(6), 3736-3760.

lx. Sekiguchi, Tomoki, James P.Burton, dan Chris J. Sablynski. 2008. The Role of Job Embeddness on Employee Performance: The Interactive Effect with Leader-Member Exchange and Organization-Based Self-Esteem. Personnel Psychology. Evidence-based HRM: a Global Forum for Empirical Scholarsh. 61(4), 761-792

lxi. Setialestari, Susan. 2015. Hubungan antara Job Embeddedness dengan Turnover Intention pada Para Pemimpin Lini di Bank X. Thesis: Universitas Pendidikan Indonesia.

lxii. Siengthai, Sununta dan Patarakhuan Pila-Ngarm. 2015. The Interaction effect of Job Redesign and Job Satisfaction on Employee Performance. 4(2), 162-180. 
lxiii. Simone, Silvia De, Anna Planta, dan Gianfranco Cicotto. 2018. The role of job satisfaction, work engagement, self-efficacy, and agentic capacities on nurses turnover intention and patient satisfaction. Applied Nursing Research. 39, 130-140.

lxiv. Srimindarti, Ceacilia, Rachmawati Meita Oktaviani, dan Pancawati Hardiningsih. 2017. Antecendents of Job Satisfaction and the Influence on Turnover Intention. Jurnal Dinamika Manajemen (JDM). 8(2), 177-187.

lxv. Thomas, W. H. NG, dan Daniel C. Feldman. 2009. Occupational embeddedness and job performance. Journal Of Organizational Behaviour. 30(7), 863- 891.

lxvi. Valaei, Naser dan Shokouh Jiroudi. 2016. Job satisfaction and Job Performance in the media idustry. A synergistic application of partial least squares path modelling. Asia Pasific Journal of Marketing an Logistics. 28(5), 984-1014.

lxvii. Veithzal Rivai, 2004. Manajemen Sumber Daya Manusia Untuk Perusahaan. Cetakan Pertama. PT. Raja Grafindo Persada: Jakarta.

lxviii. Watrous, Kristen M, Ann H. Huffman, dan Robert D. Pritchard. 2006. When Coworkers and Managers Quit: The Effect of Turnover and Shared Values on Performance. Journal of Business and Psychology. 21, (1), 103-126.

lxix. Widodo, Rohadi, 2010. Analisis Pengaruh Keamanan Kerja Dan Komitmen Organisasional Terhadap Turnover Intention Serta Dampaknya Pada Kinerja Karyawan Outsourcing (studi pada PT. PLN Persero APJ Yogyakarta). Thesis: MM UNDIP.

lxx. Zimmerman, Ryan D dan Todd C. Darnold. 2007. The Impact of Job Performance on Employee Turnover Intentions and the Voluntary turnover process. Emerald Group Publishing Limited. 38(2), 142-158. 